\title{
Enhanced Expression of Plasma Membrane Intrinsic Protein 2 Improves Cotton Fiber Length and Potential Economic Viability of Gossypium Arboreum
}

\section{Hafsa Amat-ur-Rasool}

University of the Punjab Quaid-i-Azam Campus: University of the Punjab

Ayesha Latif

University of the Punjab Quaid-i-Azam Campus: University of the Punjab

Aneela Yasmeen

University of the Punjab Quaid-i-Azam Campus: University of the Punjab

Naila Shahid

University of the Punjab Quaid-i-Azam Campus: University of the Punjab

\section{Saira Azam}

University of the Punjab Quaid-i-Azam Campus: University of the Punjab

Aftab Bashir

Forman Christian College

Tayyab Husnain

University of the Punjab Quaid-i-Azam Campus: University of the Punjab

Abdul Qayyum Rao ( $\nabla$ qayyumabdul77@yahoo.com )

University of the Punjab Quaid-i-Azam Campus: University of the Punjab https://orcid.org/0000-0001-

9269-3307

\section{Wayne Grant Carter}

University of Nottingham

Ahmad Ali Shahid

University of the Punjab Quaid-i-Azam Campus: University of the Punjab

\section{Research Article}

Keywords: Aquaporins, Desi cotton, Gossypium arboretum, PIP2 gene, Transgenic plants

Posted Date: August 3rd, 2021

DOl: https://doi.org/10.21203/rs.3.rs-723682/v1 
License: (c) (i) This work is licensed under a Creative Commons Attribution 4.0 International License. Read Full License 


\section{Abstract}

Background: Gossypium arboreum is a cotton crop native to tropical and subtropical regions that are naturally resistant to Cotton Leaf Curl Virus (CLCuV). However, its cultivation is unfavorable due to the lower quality and shorter fiber length of cotton when compared to the market leading Gossypium hirsutum. Plasma membrane intrinsic protein 2 (PIP2) is an aquaporin responsible for the transport of water and small molecules across cellular membranes. This fluid transport influences cell elongation and cotton fibre development. Hence, increased PIP2 expression may yield plants with enhanced fiber qualities including length.

Methods and Results: To test this hypothesis, G. arboretum was transformed with a PIP2 gene construct (35SCpPIP2)using the Agrobacterium-mediated shoot apex cutting method. Relative expression of the CPPIP2 gene in transgenic plants increased up to 35-fold when compared with non-transgenic controls. Transgenic plants displayed a corresponding increase of staple length (up to 150\%) when compared with non-transgenic controls. Transgene integration was examined using FISH and karyotyping and revealed the presence of a single transgene located on chromosome 6 .

Conclusion: Since G. arboreum is naturally whitefly and CLCuV resistant, this improvement of fiber length evidenced for CpPIP2 transgenic plants renders their crop production more economically viable.

\section{Introduction}

Cotton is the primary source of fiber for garment production within the textile industry. Cotton crops (also known as white gold) are cultivated globally but especially in the tropics and subtropics including Pakistan; the fourth largest cotton producer worldwide[1]. Gossypium arboreum(desi cotton) (Family Malvaceae)is native to India and Pakistan and is adiploid (2n) cotton species[2]. Gossypium hirsutum is a tetraploid product of hybridization between the diploids $G$. arboreum and G. raimondii. G. hirsutum is the most widely cultivated cotton species and is utilized for $\approx 90 \%$ of the world's cotton production. However, G. hirsutum is vulnerable to infection by cotton leaf curl virus (CLCuV). By comparison, $G$. arboretum carries genes that confer resistance to CLCuV infection [2,3],yet it is only responsible for $\approx 2 \%$ of total world cotton production. This difference in the cultivation trends between these two cotton plants in part reflects the benefits of longer fiber length: upto $30 \mathrm{~mm}$ for $G$. hirsutum compared to $\approx 15 \mathrm{~mm}$ for G. arboreum $[4,5]$. Fiber length influences the strength, evenness, and the ability to spin fibers to produce the final yarn. Longer fibers can be more efficiently spun into yarn, hence there is a benefit to cotton breeding that increases fiber length, if achieved without a compromise in fiber quality.

Calotropis procera (Milkweed)(Family Asclepiadaceae)is a wild perennial shrub, native to parts of Asia and Africa. C. procera is cultivated in South America and the Caribbean Islands for fiber production and produces cotton of relatively high tensile strength [6-8].C. procera produces seed fibers that are silky white and relatively long $(\approx 30-45 \mathrm{~mm}$ length) and utilized for pillow stuffing, weaving of cloth, and 
surgical cotton wool $[8,9]$. The relatively high C.procera fiber length in part relates to the expression of aquaporin proteins that function in cell expansion[3, 10-13].

Aquaporins are small integral plasma membrane proteins responsible for the transport of water and small molecules across the cell membrane. This fluid transport influences cell elongation and fibre development [3]. Plasma membrane intrinsic proteins (PIPs), a subclass of aquaporins, play a role in fiber cell elongation by maintaining turgor pressure. PIPs constitute the largest group of aquaporins and are further subdivided into PIP1 and PIP2 proteins.PIP2 proteins display higher water transport activity than PIP1 and improve a plant's tolerance against drought by maintaining osmotic balance, water use efficiency, and water retention [14-17].

Therefore, the potential exists for exploitation of aquaporins such as PIP2,through their incorporation into other cotton plant species to potentially improve fiber length and fiber quality[18].The present study details a biotechnological approach to attempt to improve cotton fiberporpertiesof $G$. arboreumFBD-1 (Four Brothers Desi-1), a local Pakistani G. arboreum cotton variety. G. arboreum FBD-1 was transformed with a PIP2gene construct isolated from $C$. procera. Cotton fiber properties including fiber length were then compared with non-transgenic control plants.

\section{Materials And Methods Source of plant material}

The G.arboreumFBD-1variety of cotton was selected basis on its high germination percentage and yield. Seeds of FBD1 were obtained from the Four Brothers Group of Pakistan on a research collaboration basis. Recombinant plasmid pGA482 containing the 35SCpPIP2 gene construct was provided by Forman Christian College, Lahore, Pakistan.

\section{Computational analysis of the PIP2 construct}

The nucleotide sequence of theCpPIP2 gene construct (that was used to transform G.arboreum) was translated into a protein sequence using the online tool EMBOSS-Transeq (https://www.ebi.ac.uk/Tools/st/emboss_transeq/). The molecular structure of PIP2 protein was then modelled from the amino acid sequence using the SWISS-MODEL Server (https://swissmodel.expasy.org/). Since there is not a 3D structure available for $C$. proceraPIP2 protein in the Protein Data Bank (PDB), a 3D structure of spinach aquaporin SoPIP2 (PDB ID: 4IA4) was used as a template for protein modelling. Structures of SoPIP2 and CpPIP2 were compared using the FATCAT server (http://fatcat.sanfordburnham.org/fatcat-cgi/cgi/fatcat.pl?-func=pairwise) to determine the confidence of the newly built protein structure. 


\section{Amplification of the PIP2 construct in E. coli and transformation of Agrobacterium tumefaciens}

The pre-cloned 35SCPPIP2construct[11] was amplified in E. coli strain TOP10. The purified recombinant plasmid pGA482 containing the CPPIP2 gene was confirmed by polymerase chain reaction (PCR) amplification with the gene-specific primers (forward:5'-CCACCCCTACTCCAAAAATG-3'; reverse: 5'AATCCCACACCGCAGATAG-3'). The PCR mix was comprised of $1 \mu \mathrm{L}$ of plasmid, $2 \mu \mathrm{L}$ of $10 x$ PCR buffer (Fermentas cat\# B34), $2 \mu \mathrm{L}$ of $2 \mathrm{mM}$ dNTPs, $1 \mu \mathrm{L}$ of $25 \mathrm{mMMgCl}_{2}, 2 \mu \mathrm{L}$ of each of forward and reverse primers (10pM) and $0.5 \mu \mathrm{L}$ of Taq Polymerase enzyme $5 \mathrm{U}$ (Fermentas cat\# EP0071) and deionized water to a $20 \mu \mathrm{Lfinal}$ reaction volume. PCR was performed at $95^{\square} \mathrm{Cfor} 5 \mathrm{~min}$ for $1 \mathrm{cycle}$, and then 35 cycles of $95^{\square} \mathrm{Cfor} 45 \mathrm{~s}, 63^{\complement} \mathrm{Cfor} 45 \mathrm{~s}$ and $72^{\square} \mathrm{C}$ for $1 \mathrm{~min}$, and then a final amplification at $72^{\square} \mathrm{C}$ for $10 \mathrm{~min}$. The recombinant plasmid was then transformed into Agrobacterium tumefaciens strain LBA4404 by electroporation using an electroporator (Bio-Rad, California, USA). The transformed A. tumefaciens cells were then incubated on ice for 2 minutes and diluted with $1 \mathrm{mLYeast}$ extract peptone (YEP) broth and incubated at $30^{\circ} \mathrm{C}$ for 3 hours at $200 \mathrm{rpm}$. Then, $100 \mu \mathrm{L}$ of cultured cells were plated on YEP medium supplemented with $50 \mu \mathrm{g} / \mathrm{mL}$ kanamycin and grown at $30^{\square} \mathrm{C}$. Transformed $A$. tumefaciens colonies were isolated and screened again to confirm the gene insert by PCR, using the gene-specific primers.

\section{Transformation of the CpPIP2 gene into G. arboretum}

Cotton seeds were de-linted with concentrated sulphuric acid, and then surface sterilized with $0.1 \% \mathrm{HgCl}_{2}$ and $0.1 \%$ sodium dodecyl sulphate and rinsed thoroughly with sterilized distilled water. The sterilized cotton seeds were then germinated in the dark at $30^{\square} \mathrm{C}$. The germinated embryos of 30-36 hr were used for Agrobacterium-mediated transformation as per the method of Rao et al.(2011)[19].The explants were incubated with Agrobacterium (overnight grown and suspended in Murashige and Skoog(MS) broth) for 30-60 min at $28^{\complement} \mathrm{C}$ in the dark. The shoot apex explants were then blot-dried on sterile filter paper and placed into semi-solid MS (minimal growth medium) plates supplemented with cefotaxime $(100 \mu \mathrm{g} / \mathrm{mL})$. Several untreated shoot apexes injured similarly were Agrobacterium-treated and plated as controls. The healthy plantlets were then transferred to test tubes containing MS and supplemented with $50 \mu \mathrm{g} / \mathrm{mL}$ kanamycin and $100 \mu \mathrm{g} / \mathrm{mL}$ cefotaxime and allowed to grow under $60 \mu \mathrm{E} \mathrm{m}^{-2} \mathrm{~s}^{-1}$ light for $16 / 8 \mathrm{hrlight} /$ dark cycle, for in vitro growth at $28^{\square} \mathrm{C} \pm 2^{\square} \mathrm{C}$ for $2-3$ months.

\section{Acclimatization of tissue-cultured cotton plants}

After attaining a height of approximately 6inches, $G$. arboreum seedlings in glass tubes were transferred to sterilized soil pots of 6 -inch diameter. They were then covered with polythene bags for gradual acclimatization to a culture room temperature environment, starting from 15 min and gradually 
increasing to a full day in a culture room. The plants were further acclimatized to sunlight for hardening in a similar fashion as above and then shifted to a field tunnel.

\section{Detection of transgenic cotton plants}

Genomic DNA from putative transgenic cotton plants was isolated using a Favor Prep Plant Genomic DNA Extraction Kit (cat \#FAPGK 001, Favorgen Biotech Corp.). All the primers used in this study were designed using Primer Premier v3.0. The gene-specific primers were:forward primer 5'CCACCCCTACTCCAAAAATG-3' and reverse primer 5'-AATCCCACACCGCAGATAG-3'.

\section{Gene expression analysis of transgenic cotton plants}

Transgenic cotton plants from the T1 generation were used for CpPIP2gene expression analyses. Young leaves from transgenic cotton plants were used for total RNA extraction according to the protocol of Gul et al. (2020)[20]. The cDNA was synthesized using aRevertAidFirst Strand cDNA Synthesis Kit (cat \# $\mathrm{K} 1621$ Thermo Fischer Scientific) in a reaction mixture comprised of $4 \mu \mathrm{L} 5 \mathrm{x}$ reaction buffer, $2 \mu \mathrm{L} 10 \mathrm{mM}$ dNTP mix, $1 \mu$ LRiboLock RNase inhibitor $(20 \mathrm{U} / \mu \mathrm{L})$ and $1 \mu \mathrm{L}$ RevertAid M-MuLV Reverse Transcriptase $(200 \mathrm{U} / \mu \mathrm{L})$, in a final reaction volume of $20 \mu \mathrm{L}$. The reaction was incubated at $42^{\square} \mathrm{C}$ for 60 minutes and then terminated by heating at $70^{\square} \mathrm{C}$ for 5 minutes. Quantitative real-time PCR (qRT-PCR) was performed using MaximaSYBR Green/ROX (cat \# K0229 Thermo Fischer Scientific) using glyceraldehyde-3phosphate dehydrogenase (GAPDH) as an internal (reference) standard. For each reaction, 7.5 $\mu \mathrm{L}$ of Maxima ${ }^{\circledR}$ SYBR Green/ROX qPCR Master Mix (2x), $1 \mu \mathrm{L}$ forward primer, and $1 \mu \mathrm{L}$ reverse primer was mixed and made up to a final volume of $15 \mu \mathrm{l}$ by the addition of nuclease-free water. Real-time PCR was performed after an initial denaturation at $95^{\square} \mathrm{C}$ for $5 \mathrm{~min}$, and then performed at $95^{\square} \mathrm{C}$ for $30 \mathrm{~s}, 51^{\square} \mathrm{C}$ for $45 \mathrm{~s}$, and $72^{\square} \mathrm{C}$ for $1 \mathrm{~min}$, for a total of 35 cycles. The forward primer $5^{\prime}$-AGGAATTGCTTGGGCTTTCG-3' and reverse primer 5'-TGGAATGCCTTCACGAATCC-3' were used for gene amplification. The qPCR analysis was run on PikoReal real-time PCR system (Thermo Fisher Scientific).

\section{Fiber length analysis}

Mature cotton bolls were harvested upon maturity and fibers were separated from cotton seeds. Fiber samples from transgenic and non-transgenic cotton plants were dispatched to the Central Cotton Research Institute, Multan, Pakistan, for fiber length, strength, micronair value, uniformity index and ginning out turn percentage (GOT\%) analyses.

\section{Fluorescent in situ Hybridization (FISH)}


FISH was employed to determine the chromosomal location of the CpPIP2 gene in transgenic plants as described by Gul et al. (2020) [20].

\section{Statistical analysis}

Statistical comparisons between plants were performed by one-way analysis of variance (ANOVA), with Dunnett's multiple comparison test, using GraphPad Prism (version 7)(GraphPad Software Inc., San Diego, California, USA).Significant differences were set at a $p$-value of $<0.05$. Data presented as histograms represent experimental means \pm SD.

\section{Results}

\section{Computational Analysis of PIP2}

To examine the potential benefit of incorporation of the aquaporin PIP2 into G. arboretum, a molecular modelling approach was first undertaken. A 3D protein model of the transformed $C p P I P 2$ nucleotide sequence was built via the SWISS-MODEL server, using spinach (Spinacia oleracea) aquaporin SoPIP2 (PDB ID: 4IA4) as a template. The resulting 3D model showed that this protein is tunnel-shaped with six transmembrane domains (Figures 1A \& 1B).A FATCAT server calculation showed that there was an $\approx 86 \%$ similarity of CPPIP2with the aquaporin SoPIP2 (PDB ID: 4IA4). Indeed, a total of 241 amino acid residues were perfectly aligned between the two proteins and the root mean square distance of the aligned regions was $0.37[21]$. The superimposition of the two structures (Figure 1C) confirms the pore-forming shape of the $C P P I P 2$ gene product and suggests that after incorporation into a recipient plant (G. arboretum), the protein may be useful for improved water and ion flux; traits conducive to improved fiber elongation.

\section{Transformation of the CpPIP2construct}

Transformation of G. arboreum with the CPPIP2 gene was carried out using an A. tumefaciens strain, LBA4404. A total of 4055 shoot apices of the germinated embryos were injured and co-cultivated with $A$. tumefaciens containing the CpPIP2 gene. Only 231 plantlets survived in MS-plates during the cocultivation stage, as the majority of plantlets died from either a fungal infection or an inability to develop roots or shoots. The healthy plantlets that survived the kanamycin selection for approximately two months were regarded as putatively transformed plants and were shifted to soil pots. The plants in soil pots (54) were then transferred to field tunnels after acclimatization. The transformation efficiency for $G$. arboreum was calculated as $1.3 \%$ (Table 1) according to the formula: 


\section{No of transformed plants obtained \\ Transformation Efficiency $=$ \\ Total embryos transformed}

To verify the transformation and production of transgenic cotton plants, amplification of the 844bp PCR insert corresponding to the CPPIP2 gene was undertaken, as shown in Figure 2.

Table 1

Numerical data for transformation experiments and transformation efficiency.

\begin{tabular}{|llllllll|}
\hline $\begin{array}{l}\text { Exp. } \\
\text { No. }\end{array}$ & $\begin{array}{l}\text { Agrobacterium } \\
\text { treated } \\
\text { embryos }\end{array}$ & $\begin{array}{l}\text { Embryos } \\
\text { that died on } \\
\text { MS plates }\end{array}$ & $\begin{array}{l}\text { Plants } \\
\text { transferred } \\
\text { to tubes }\end{array}$ & $\begin{array}{l}\text { Plants } \\
\text { died in } \\
\text { tubes }\end{array}$ & $\begin{array}{l}\text { Plants } \\
\text { transferred } \\
\text { in pots }\end{array}$ & $\begin{array}{l}\text { Plants } \\
\text { died } \\
\text { in } \\
\text { pots }\end{array}$ & $\begin{array}{l}\text { Plants } \\
\text { shifted } \\
\text { to } \\
\text { tunnels }\end{array}$ \\
\hline Total & 4055 & 3824 & 231 & 82 & 149 & 95 & 54 \\
\hline
\end{tabular}

\section{Expression analysis of the CpPIP2 insert in G. arboreum}

Total cDNA isolated from transgenic G. arboreum plants was used to analyze PIP2 gene expression viaqRT-PCR. Relative gene expression data were normalized with GAPDH as an internal control using the ${ }^{\Delta \Delta} \mathrm{Ct}$ method. The relative expression of 8 transgenic plants was compared with non-transgenic controls, and each revealed a dramatic increasein PIP2 gene expression. Increases in PIP2 gene expression of $36.8,22.5,17.7,15.0,35.0,32.3,20.7$ and23.4-fold were observed for the transgenic plants TP1, TP2, TP3, TP4, TP5, TP6, TP7 and TP8,respectively (Figure 3).

\section{Morphological assessment of cotton fibers}

An assessment of fiber quality was undertaken to consider the effects of the CpPIP2 gene transgene on cotton properties. PIP proteins are involved in trichome elongation and stress tolerance, hence fiber length, strength, micronaire value, uniformity index, and GOT\% were analyzed. Expression of the CpPIP2 gene in transgenic cotton plants produced a significant increase of fiber length but was without effect on the other fiber characteristics when compared with non-transgenic control plants (Figures 4 and $5 \mathrm{~A})$.Notably, an increase in fiber length was observed for all transgenic lines compared to non-transgenic controls (Figure 5A). The transgenic plant, TP1, produced the greatest increase in fiber length compared to the non-transgenic controls, followed by TP5 and TP6 (Figure $5 \mathrm{~A}, \mathrm{~B}$ ). These results are consistent with the mRNA expression data for these transgenic plants (Figure 3), indicative of a direct correlation between gene and protein expression. 


\section{Localization of $C p P I P 2$ chromosomeal integration}

Fluorescent insitu hybridization (FISH) was undertaken for the TP1 transgenic plant. The fluorescent signal was localized to chromosome 6 in the hemizygous form, confirming that the $C p P I P 2$ gene had been successfully integrated into the cotton genome (Figure 6).

\section{Discussion}

Rising global demand for cotton has highlighted the need to improve both cotton fiber quality and length. This can be achieved through the biotechnological manipulation of cotton plants. Although G. hirsutum has the market share of cotton production, it is vulnerable to whitefly and CLCuV infestation, leading to crop losses $[22,23]$.To exploit the inherent resistant nature of $G$. arboreum against both whitefly and CLCuV but with potentially improved cotton fiber traits, the CPPIP2 gene encoding a PIP2 aquaporin was introduced into $G$. arboreum.

Aquaporins comprise a diverse protein family responsible for the transport of water and solutes in plants and animals $[14,24]$.This functionality is reflected by the formation of barrel-like membrane pores, such as that for PIP2 (Fig. 1). PIP2 proteins recruit PIP1 proteins from the endoplasmic reticulum to the plasma membrane to increase water permeability [14]. In this study, G. arboreum was successfully transformed using an Agrobacterium-mediated shoot apex cut method[19] to produce transgenic plants with elevated PIP2 expression. Although transformation efficiency was relatively low (Table 1), it was still in keeping with other transgenic plant studies[25, 26]. Moreover, relative CpPIP2gene expression of transgenic plants was high(Fig. 3).

The incorporated transgene,CpPIP2,is controlled via aconstitutively active35S promoter. Hence, all successfully transformed plants displayed increased PIP2 expression. From the analysis of 8 separate plants (TP1-TP8), identification of the highest expressing transgenic plants (TP1, TP5 and TP6) was accomplished (Fig. 3). The utilization of the 35 S promoter to drive CPPIP2expression,(by comparison to thetrichome-specific promoter (GhLTP3),has previously been ulitized for gene expression studies in transgenic tobacco plants[11].Relative PIP2expression for transgenic plants was 15-38-fold higher than non-transgenic controls. For the transgenic plant, TP1, that displayed thehighest expressional increase of $P I P 2$, an increase offiber length of $150 \%(15 \mathrm{~mm}$ to $22 \mathrm{~mm})$ was observed.This beneficial increase ofcotton fiber length for transgenic plants arose without change to other integral fiber properties. Indeed, there were no significant differences between control or transgenic plants for fiber strength, micronair value (fiber fineness and maturity), uniformity index, or GOT\% (Fig. 4).

In summary, G. arboreum is not a preferred cotton cultivar due to its shorter fiber length. However, it has a natural resistance to several chewing and sucking insect infestations including the notorious whitefly, the biological vector responsible for CLCuV transmission[22, 27]. Hence, this genetically modified $G$. arboretum, with an improved fiber length without loss of fiber quality, could potentially improve the economic viability of $G$. arboreum via increased cotton yield. 


\section{Abbreviations}

CLCuV,cotton leaf curl virus; dNTPs, deoxynucleotide triphosphates; GAPDH, glyceraldehyde-3-phosphate dehydrogenase; GOT\%, ginning out turn percentage; PCR, polymerase chain reaction; PIPs, plasma membrane intrinsic proteins; TP, transgenic plant.

\section{Declarations}

\section{Acknowledgement:}

We are thankful to the Four Brothers Group of Pakistan for the provision of the plant seeds used in this study.

\section{Funding:}

Not Applicable

\section{Competing interests:}

The authors declare that they have no conflict of interest.

\section{Availability of data and materials.}

The datasets used and/or analysed during the current study are available from Dr Abdul Qayyum Rao (qayyum.cemb@pu.edu.pk) upon request.

\section{Code Availability:}

Not Applicable

\section{Authors contributions}

AQR conceived the study. HAUR carried out research work. AB and AY performed the cloning of the PIP2 gene and AL supervised the cotton transformation. NS drafted the initial manuscript and data interpretation. SA performed fiber and field analyses. AB provided the PIP2 gene construct for transformation. TH supervised the field evaluation. WGC reviewed and edited the initial manuscript and 
data analysis, to produce the finalized manuscript. AAS reviewed and approved the article for submission. All authors read and approved the final manuscript.

\section{Ethical Approval:}

Not Applicable

\section{Consent to Participate:}

Not Applicable

\section{Consent to Publish}

The authors confirm that this manuscript has been read and approved by all authors, and is not under consideration for publication elsewhere.

\section{References}

1. Shuli F, Jarwar AH, Wang X, Wang L, Ma Q (2018) Overview of the cotton in Pakistan and its future prospects. Pakistan Journal of Agricultural Research 31(4): 396-407

2. Li F, Fan G, Wang K et al (2014) Genome sequence of the cultivated cotton Gossypium arboreum. Nature genetics 46(6): p. 567

3. Mushtaq R, Shahzad K, Mansoor S, Shah ZH, Alsamadany H, Mujtaba T, Al-Zahrani Y, Alzahrani HAS, Ahmed Z, Bashir A (2018) Exploration of cotton leaf curl virus resistance genes and their screening in Gossypium arboreumby targeting resistance gene analogues. AoB PLANTS 10: ply067; doi: 10.1093/aobpla/ply067

4. Kulkarni VN, Khadi BM, Maralappanavar MS et al (2009) The worldwide gene pools of Gossypium arboreum L. and G. herbaceum L., and their improvement, in Genetics and genomics of cotton. Springer: USA. p. 69-97

5. Paterson AH, Genetics and Genomics of Cotton. Vol. (3). 2009, New York: Springer Science \& Business Media. 509

6. Bajwa KS, Shahid AA, Rao AQ et al (2013) Expression of Calotropis procera expansin gene CpEXPA3 enhances cotton fibre strength. AJCS 7(2):206-212

7. French AD, Kim HJ (2018) Cotton fiber structure, in Cotton Fiber: Physics, Chemistry and Biology. Springer. p. 13-39

8. Yoganandam K, Ganeshan P, NagarajaGanjesh B, Raja K (2019) Characterization studies on Calotropis procera fibers and their performance as reinforcements in epoxy matrix. Journal of Natural Fibers, 2019: p. 1-13 
9. Oun AA, Rhim JW (2016) Characterization of nanocelluloses isolated from Ushar (Calotropis procera) seed fiber: Effect of isolation method. Materials Letters. 168: p. 146-150

10. Cheema HMN, Bashir A, Khatoon A, Iqbal N, Zafar Y, Malik KA (2010) Molecular characterization and transcriptome profiling of expansin genes isolated from Calotropis procera fibers. Electronic Journal of Biotechnology 13(6): p. 10-11

11. Aslam U, Khatoon A, Cheema HMN, Bashir A (2013) Identification and characterization of plasma membrane aquaporins isolated from fiber cells of Calotropis procera. Journal of Zhejiang University 14(7): p. 586-595

12. Hukin D, Doering-Saad C, Thomas CR, Pritchard J (2002) Sensitivity of cell hydraulic conductivity to mercury is coincident with symplasmic isolation and expression of plasmalemma aquaporin genes in growing maize roots. Planta 215(6): p. 1047-1056

13. Liu D, Tu L, Wang L, Li Y, Zhu L, Zhang X (2008) Characterization and expression of plasma and tonoplast membrane aquaporins in elongating cotton fibers. Plant cell reports 27(8): p. 1385-1394

14. Bienert MD, Diehn TA, Richet N, Chaumont F, Bienert GP (2018) Heterotetramerization of plant PIP1 and PIP2 aquaporins is an evolutionary ancient feature to guide PIP1 plasma membrane localization and function. Frontiers in plant science 9: p. 382

15. Li R, Wang J, Li S, Zhang L, Qi C, Weeda S, Zhao B, Ren S, Guo YD (2016) Plasma Membrane Intrinsic Proteins SIPIP2;1, SIPIP2;7 and SIPIP2;5 Conferring Enhanced Drought Stress Tolerance in Tomato. Scientific Reports 6: p. 31814

16. Li DD, Ruan XM, Zhang J, Wu YJ, Wang XL, Li XB (2013) Cotton plasma membrane intrinsic protein 2s (PIP2s) selectively interact to regulate their water channel activities and are required for fibre development. New Phytologist 199(3): p. 695-707

17. Akhtar S, Shahid AA, Rao AQ, Bajwa KS, Muzafar A, Latif A, Husnain T (2014) Genetic effects of Calotropis procera CPTIP1 gene on fiber quality in cotton (Gossypium hirsutum). Advancements in Life Sciences 1(4): p. 223-230

18. Ruan Y-L (2005) Recent advances in understanding cotton fibre and seed development. Seed Science Research 15(4): p. 269-280

19. Rao AQ, Irfan M, Saleem Z, Nasir IA, Riazuddin S, Husnain T (2011) Overexpression of the phytochrome $\mathrm{B}$ gene from Arabidopsis thaliana increases plant growth and yield of cotton (Gossypium hirsutum). Journal of Zhejiang University Science B 12(4): p. 326-334

20. Gul A, Hussain G, lqbal A (2020) Constitutive expression of Asparaginase in Gossypium hirsutum triggers insecticidal activity against Bemisia tabaci.Scientific Reports 10:8958

21. Ye Y, Godzik A (2003) Flexible structure alignment by chaining aligned fragment pairs allowing twists. J Bioinformatics 19(suppl_2): p. ii246-ii255

22. Iqbal M, Naeem M, Aziz U, Afzal J, Khan MA (2014) An overview of cotton leaf curl virus disease, persistant challeng for cotton production. Bulg. J. Agric. Sci., 20: 405-415

23. Majeed A, Husnain T, Riazuddin S (2000), Transformation of virus-resistant genotype of Gossypium hirsutum L. with pesticidal gene. Plant Biotechnology 17(2): p. 105-110 
24. Gomes D, Agasse A, Thiébaud P, Delrot S, Gerós H, Chaumont F (2009) Aquaporins are multifunctional water and solute transporters highly divergent inliving organisms Biochimica et Biophysica Acta 1788 1213-1228

25. Wamiq G, Akhtar S, Khan ZA, Alam P, Khan JA (2016) Development of an efficient method for regeneration and Agrobacterium-mediated transformation of cotton (Gossypium hirsutum L.) $\mathrm{cV}$. HS6. Indian J. Biotechnology 15: p. 39-47

26. Zubair M, Latif A, Rao AQ et al (2019) A Combinational Approach of Enhanced Methanol Production and Double Bt Genes for Broad Spectrum Insect Resistance in Transgenic Cotton. Mol. Biotechnol 61(9): p. 663-673

27. Din ZM, Malik TA, Azhar FM, Ashraf M (2016) Natural resistance against insect pests in cotton. 26: p. $1346-1353$

\section{Figures}
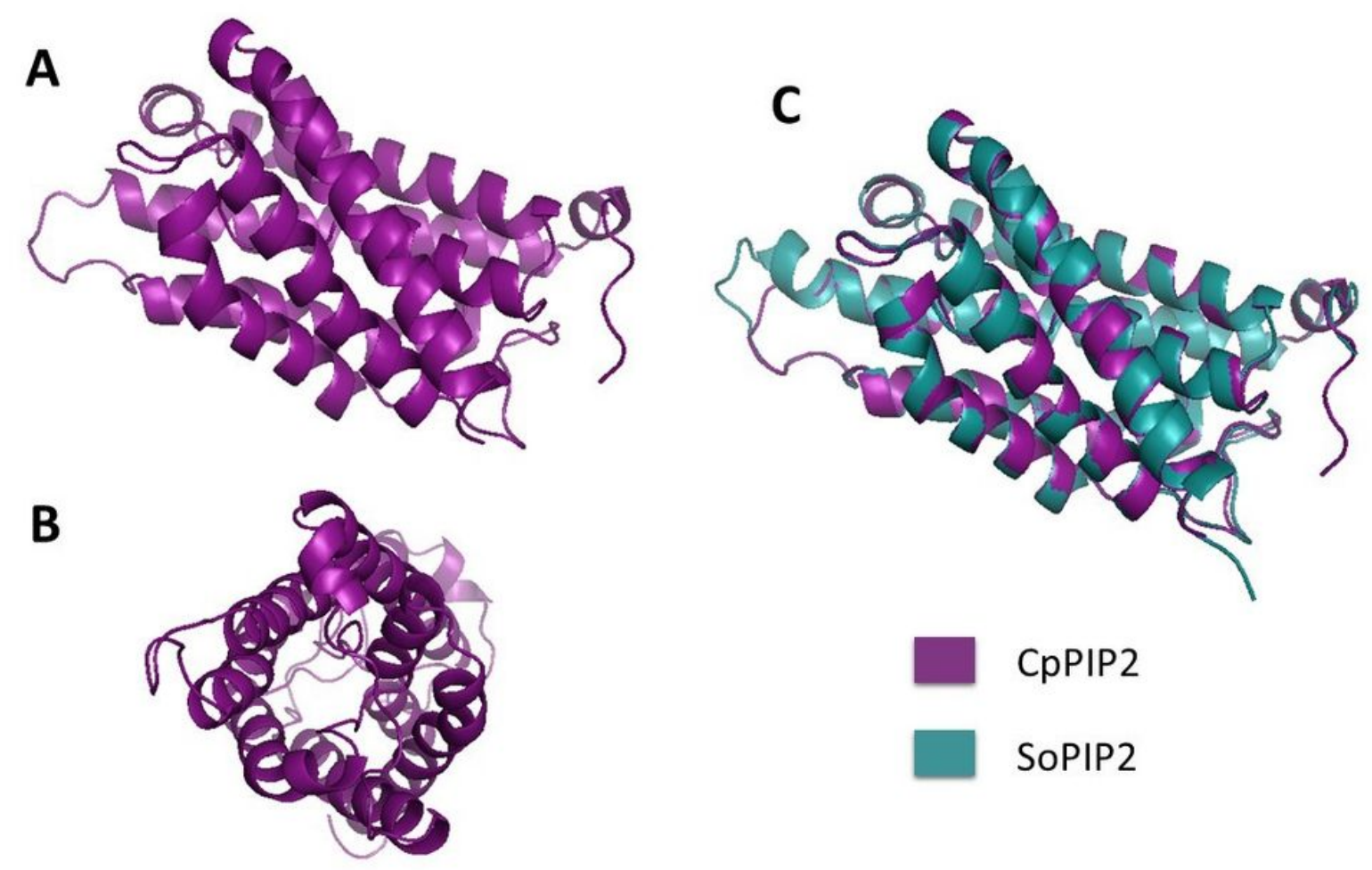

SoPIP2

\section{Figure 1}

Cartoon representations of 3D models of CpPIP2 protein. (A) Cylindrical pore-formingCpPIP2 protein. (B) CpPIP2 aquaporin showing the pore from a top viewpoint. (C) Superimposition of CpPIP2 with its template SoPIP2 (PDB ID: 4IA5). Images generated using PyMOL v1.3. 


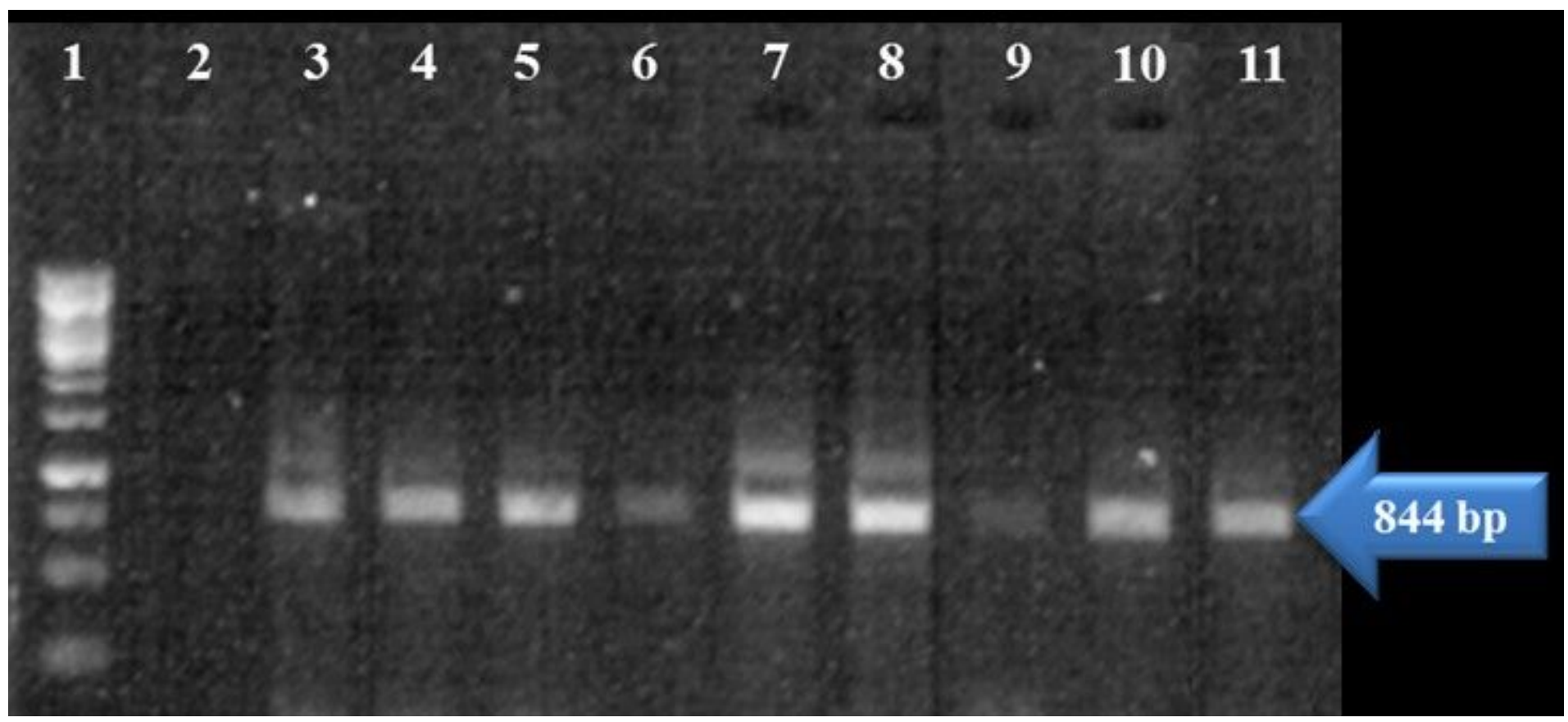

\section{Figure 2}

Confirmation of plant transformation by PCR amplification. Amplification of an 844bp PCR product confirmed CpPIP2 gene presencewithin transgenic plant lines. Lane 1: 1kb DNA Ladder; Lane 2: plant negative control; Lanes 3-11: transgenic cotton plants. 


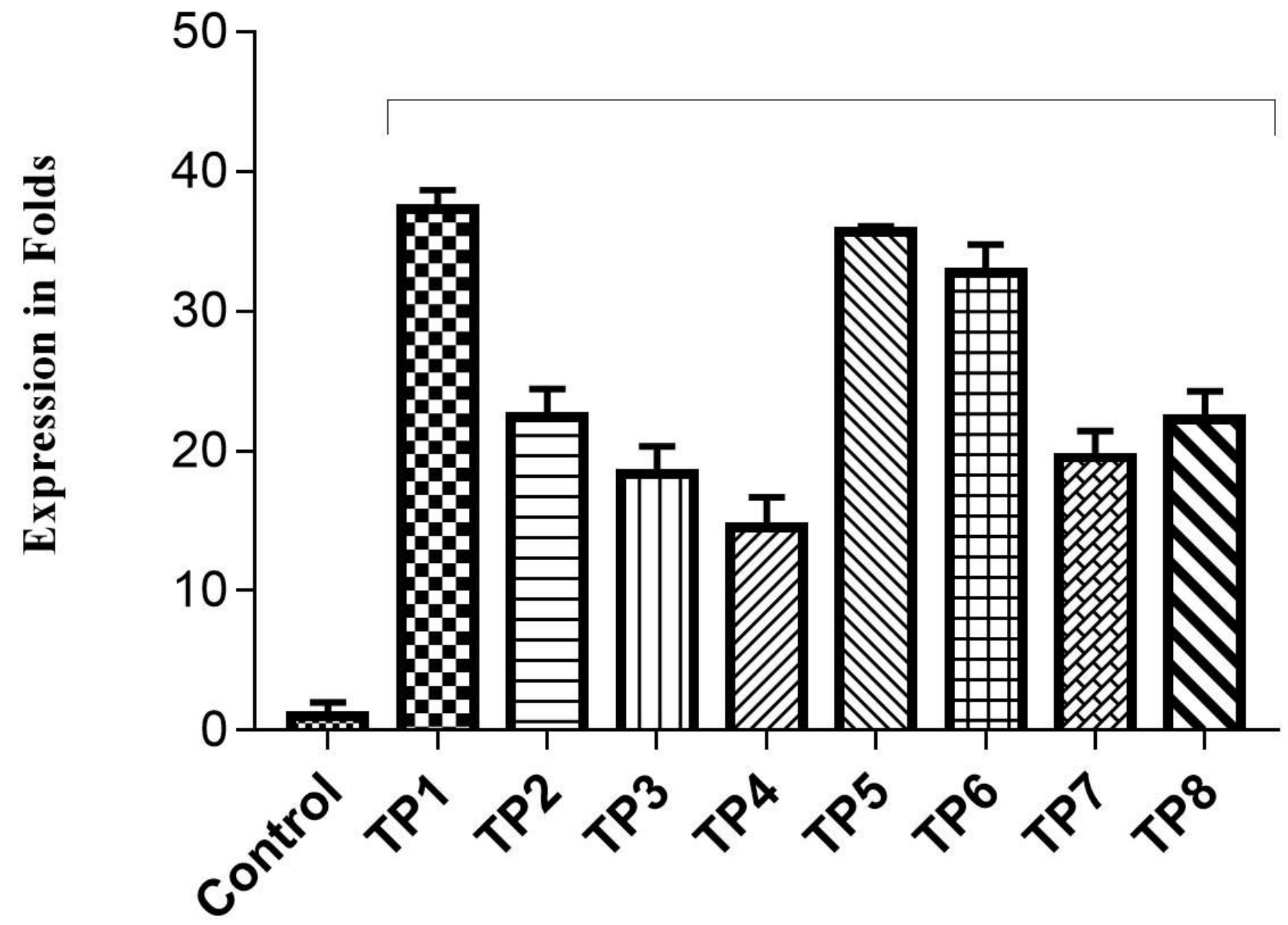

Transgenic lines

Figure 3

Expression analysis of CpPIP2within G. arboreum transgenic cotton plants.Relative expression of CpPIP2was quantified using qRT-PCR. All transgenic plants (TP1-TP8) displayed increased CpPIP2expression of between 15-38-fold higher than control plants. Histograms are representative of the mean of three independent replicates \pm SD.To assess significant changes, a one-way ANOVA was performed followed by Dunnett's multiple comparison test. All transgenic plants showed significantly

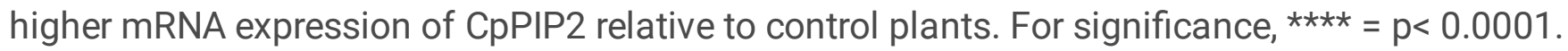




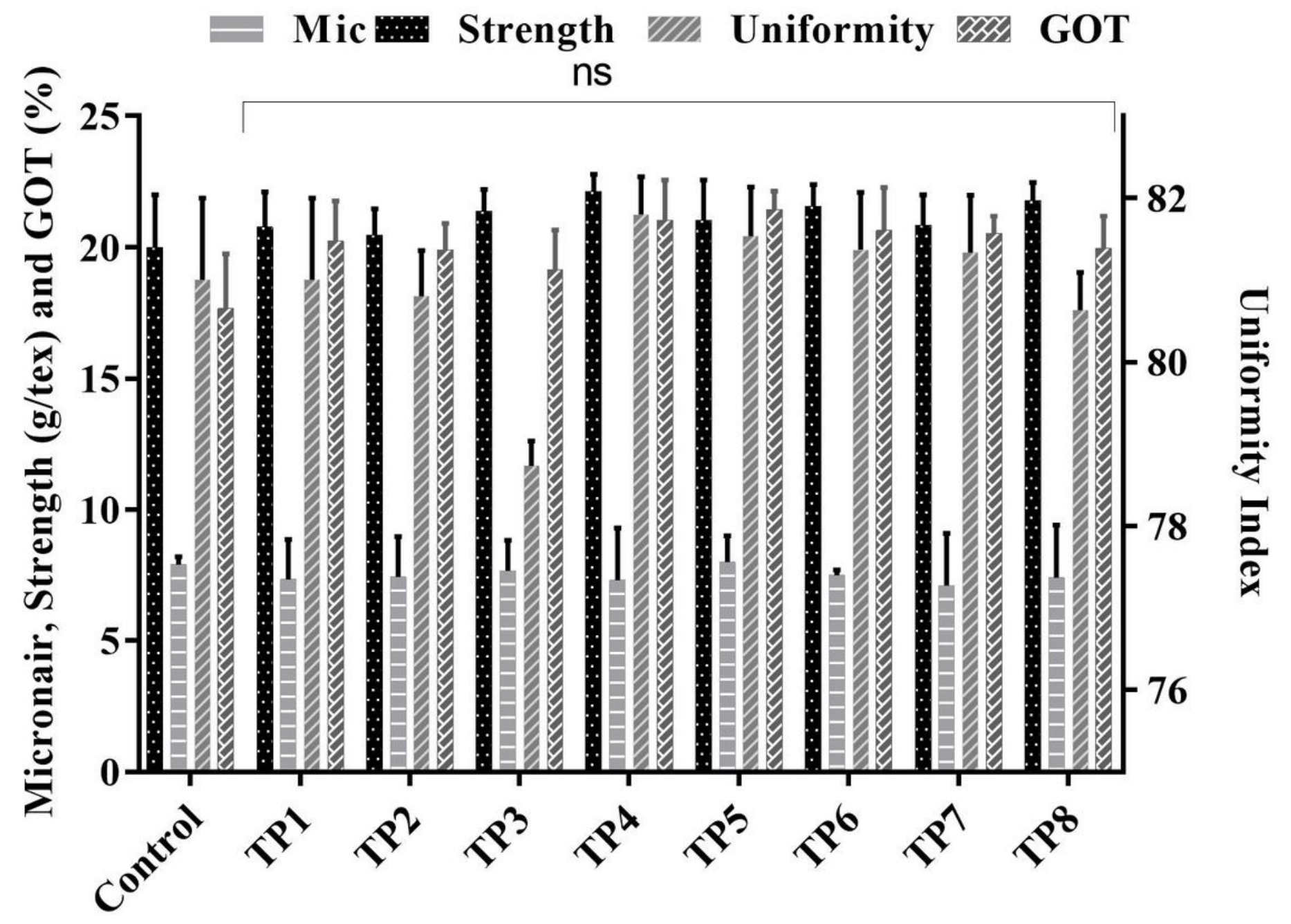

Cotton lines

Figure 4

Fiber properties of control and CpPIP2 transgenic plants. The mature bolls from T1-generation plants were analyzed. Fiber strength, micronaire value, uniformity index, and GOT\% were compared between control and CpPIP2 transgenic plants. Histograms are representative of the mean of three independent replicates $\pm S D$. To assess significant changes, a one-way ANOVA was performed followed by Dunnett's multiple comparison test. No significant differences were observed $(p>0.05)$ for any of the fiber parameters for transgenic plants when compared with control plants. 

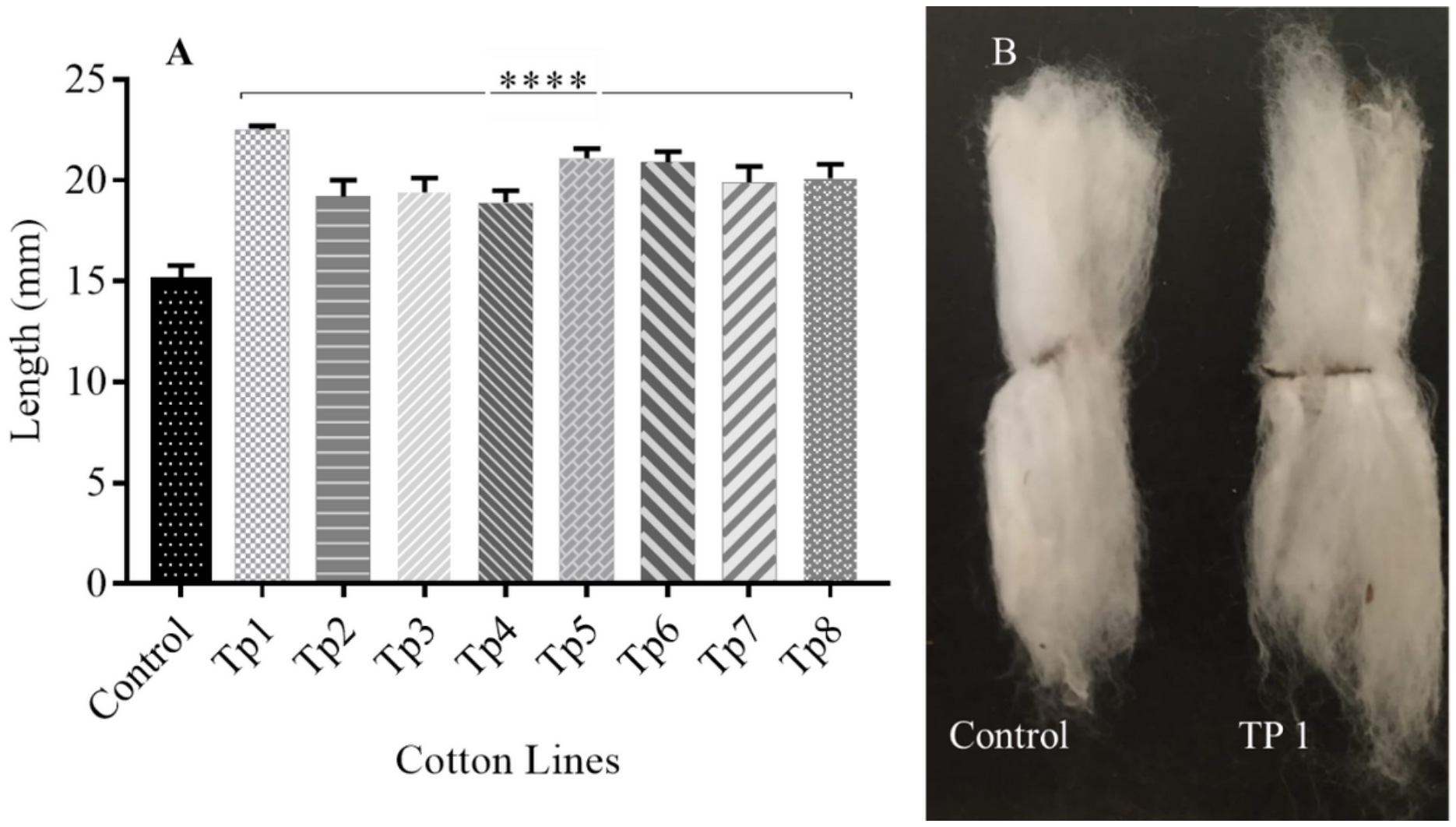

\section{Figure 5}

Fiber length of transgenic cotton plants.A. Fiber length of control and CpPIP2 transgenic plants plotted in $\mathrm{mm}$. Histograms are representative of the mean of three independent replicates \pm SD.To assess significant changes, a one-way ANOVA was performed followed by Dunnett's multiple comparison test. For significance, ${ }^{\star \star \star \star}=p<0.0001$. B. Photograph to compare thefiber length of the transgenic plant (TP1) with a non-transgenic control plant. 
Figure 6

FISH and karyotyping of CpPIP2 transgenic plants. The CpPIP2transgene was localized to chromosome number 6 in the diploid cotton genome as confirmed by fluorescence (red arrow). 